\title{
Intestinal Mucosa Development in Broiler Chickens Fed Natural Growth Promoters
}

Author(s)
Pelicano ERL1
Souza PA ${ }^{1}$
Souza HBA ${ }^{1}$
Figueiredo DF²
Boiago MM ${ }^{1}$
Carvalho $\mathrm{SR}^{1}$
Bordon VF${ }^{1}$
1 Departamento de Tecnologia - UNESP/
FCAV, Jaboticabal, SP, Brasil
2 Departamento de Morfologia e Fisiologia
Animal - UNESP/FCAV, Jaboticabal, SP, Brasil

\section{Mail Address}

Elizabete Regina Leone Pelicano

Departamento de Tecnologia

Faculdade de Ciências Agrárias e Veterinárias - Unesp

Via de Acesso Prof. Paulo D. Castellane, km 5 14.884-900. Jaboticabal, SP, Brazil

Telephone: (55) 1632092675 , ext. 245

Fax: $\quad$ (55) 1632092675

E-mail: erlpelicano@yahoo.com.br

\section{Keywords}

Broilers, crypt depth, growth promoters, intestinal morphology, villus density, villus height.

\section{Acknowledgements}

The authors thank Fundação de Amparo à Pesquisa do Estado de São Paulo (FAPESP) for financial support.

\section{ABSTRACT}

This study evaluated the use of probiotics and prebiotics on the histological and morphological indexes of the intestinal mucosa of broilers at 21 days of age. Thirty-six birds were randomly distributed in a $3 \times 3$ factorial arrangement, considering 3 probiotics and prebiotics sources in the diet. There were 9 treatments with 4 repetitions. Diet treatments were: 1 - Control (without growth promoters); 2 - Bacillus subtilis-based probiotic (Pro 1); 3 - Probiotic (Pool) based on Lactobacillus acidophilus and casei, Streptococcus lactis and faecium, Bifidobacterium bifidum and Aspergillus oryzae (Pro 2); 4 - Prebiotic based on Phosphorylated Mannanoligosaccharide (MOS) and Organic Acidifier (OA) (Pre 1); 5 MOS-based prebiotic (Pre 2); 6 - Pro 1 + Pre 1; 7 - Pro 1 + Pre 2; 8 - Pro 2 + Pre 1; 9 - Pro $2+$ Pre 2 . Higher villus height $(\mathrm{VH})(\mathrm{p}<0.01)$ were seen in the duodenum of birds fed diets without prebiotics, whereas birds fed Bacillus subtilis-based probiotic and birds fed prebiotic based on MOS and OA showed higher VH $(p<0.01)$ in jejunum and ileum. Greater crypt depths (CD) $(p<0.01)$ were observed in the duodenum, jejunum and ileum of birds receiving $B$. subtilis, and in the duodenum and jejunum of birds fed diets without prebiotics. Significant interaction $(p<0.01)$ between the evaluated factors was seen for both, $\mathrm{VH}$ and $C D$, in the three intestinal portions. Greater VH was obtained in duodenum, jejunum and ileum with the use of probiotics and prebiotics and greater CD with the use of probiotics, in relation to the control group. There was no difference in villus density (VD) between birds fed diets without additives or diets containing probiotics and prebiotics. Nevertheless, there was a significant interaction $(p<0.05)$ between the evaluated factors for VD in the duodenum. Concluding, beneficial effects were seen in histological indexes of the intestinal mucosa with the use of probiotics and prebiotics at 21 days of age.

\section{INTRODUCTION}

The intestinal epithelium acts as a natural barrier against pathogenic bacteria and toxic substances that are present in the intestinal lumen. Stressors, pathogens, and chemical substances, among others, cause disturbances in the normal microflora or in the intestinal epithelium that may alter the permeability of this natural barrier, facilitating the invasion of pathogens and prejudicial substances, modifying the metabolism, the ability to digest and absorb nutrients, and leading to chronic inflammatory processes at the intestinal mucosa (Hofstad, 1972; Podolsky, 1993; Oliveira, 1998). Consequently, there is decrease in the villus, increase in the cell turnover and decrease in the digestive and absorptive activities (Visek, 1978).

Since absorption is totally dependent on the mechanisms that occur in the intestinal mucosa, the manipulation of probiotics (microbial supplements comprised of specific bacteria or fungi) together with 
Pelicano ERL, Souza PA, Souza HBA, Figueiredo DF, Boiago MM, Carvalho SR, Bordon VF prebiotics (non-digestible ingredients that are beneficial to the host because they selectively stimulate growth and/or the activity of certain bacteria in the intestine) have been used to improve performance and, consequently, the energetic efficiency of the intestine (Dobrogosz et al., 1991; Bradley et al., 1994; Spring, 1996; Savage et al., 1996, Hofacre et al., 2003; Pelicano et al., 2004).

The action of probiotics can be explained by some mechanisms such as the production of antimicrobial substances and organic acids, protection of the villi and absorptive surfaces against toxins produced by pathogens, as well as the stimulation of the immune system (Vicent, 1959; Dobrogosz et al., 1991; Ewing \& Cole, 1994; Walker \& Duff, 1998; Pelicano et al., 2002).

On the other hand, prebiotics effects are based on reduction of the growth of many pathogenic or nonpathogenic intestinal bacteria by means of the $\mathrm{pH}$ reduction that results from increased lactic acid levels in the ceca (Choi et al., 1994). Some bacteria may recognize binding sites in such molecules as if they were on the mucosa surface, and the intestinal colonization by pathogenic bacteria is thus reduced. Therefore, there is lower incidence of infectious processes, and the functions of secretion, digestion and absorption of nutrients can be appropriately performed by the mucosa (lji \& Tivey, 1998). Positive effects of the use of prebiotics on the instestinal mucosa have been reported, among which, a significant increase in villus height in the three segments of the small intestine of birds aged one-week and supplemented with MOS (Macari \& Maiorka, 2000) and the increased duodenal villus height at 21 and 42 days old in birds fed prebiotics based on fructooligosaccharides (FOS), lactose, mannose and saccharose (Dionisio, 2001).

The present study evaluated the effects of different prebiotics, probiotics and their association on the histological and morphological indexes of the intestinal mucosa of broilers aged 21 days.

\section{MATERIAL AND METHODS}

The study was conducted at the Faculdade de Ciências Agrárias e Veterinárias - UNESP/FCAV, Jaboticabal, São Paulo, Brazil, and the further analyses were carried out at the Laboratories of Optical and Scanning Electron Microscopy (Departamento de Morfologia e Fisiologia Animal, UNESP/FCAV).

\section{- Biological material}

Initially the experiment was carried out using 1,260 male chicks from Cobb strain. At the end of the experimental period (21 days of age) four birds per treatment (36 birds) were slaughtered for histomorphological analysis of the intestinal mucosa.

\section{- Bird Management}

Birds were housed in a conventional masonry poultry house and distributed in pens measuring $3.20 \mathrm{~m} \times 1.46 \mathrm{~m}$. Standard commercial management was used throughout the experimental period. The pens had been previously covered with approximately $5 \mathrm{~cm}$ of wood shavings and equipped with tubular chick feeders and pressure drinkers. Infrared lamps were used as heating source in the first days of rearing. From the second week to the end of the experiment, chick equipments were changed for 20-kg tubular feeders and automatic bell-drinkers.

The birds were vaccinated against Marek's disease at the hatchery and against Newcastle and Gumboro's diseases at the poultry house.

Environment temperature and humidity were recorded daily. Adequate curtain and fan management was performed to assure optimal environmental conditions. Water and feed were provided ad libitum.

\section{- Experimental design and treatments}

The birds were distributed in a completely randomized design according to a $3 \times 3$ factorial, with 3 sources of probiotics in the feed (no probiotics, Pro 1 , Pro 2) and 3 sources of prebiotics in the feed (no prebiotics, Pre 1, Pre 2). The morphometric analysis and ultra-structure analysis of the intestinal mucosa was performed in samples collected from 36 birds ( 9 treatments, 4 birds/treatment).

Treatments were as follows according to the growth promoter added to the diet: 1 - Control (without growth promoters); 2 - Bacillus subtilis-based probiotics (Pro 1); 3 - Probiotics (Pool) based on Lactobacillus acidophilus and casei, Streptococcus lactis and faecium, Bifidobacterium bifidum and Aspergillus oryzae (Pro 2); 4 - Prebiotics based on Phosphorylated Mannanoligosacharide (MOS) and organic acidifier (OA) (Pre 1); 5 - MOS-based prebiotics (Pre 2); 6 - Pro $1+$ Pre 1; 7 - Pro 1 + Pre 2; 8 - Pro $2+$ Pre 1; 9 - Pro $2+$ Pre 2

\section{- Growth promoter dosages}

The commercial products were added to the diets according to the dosages recommended by the manufacturers:

- Bacillus subtilis-based probiotics (Pro 1) added at $150 \mathrm{~g} /$ ton diet, from 1 to 21 days old; 
Pelicano ERL, Souza PA, Souza HBA, Figueiredo DF, Boiago MM, Carvalho SR, Bordon VF
- Probiotics based on Lactobacillus acidophilus and casei, Streptococcus lactis and faecium, Bifidobacterium bifidum and Aspergillus oryzae (Pro 2) at $1 \mathrm{~kg} /$ ton diet, from 1 to 21 days old;

- Prebiotics based on MOS and OA (Pre 1) added at $2 \mathrm{~kg} /$ ton diet, from 1 to 21 days old;

- MOS-based prebiotics (Pre 2) added at $1 \mathrm{~kg} / \mathrm{ton}$ diet, from 1 to 21 days old.

\section{- Experimental diets}

Feeders were refilled using scoops specific for each treatment in order to prevent contamination of microorganisms among treatments, and the same was made for the cleaning material used to wash the drinkers.

Birds were given feed and water ad libitum throughout the rearing period. Initial diets (1-21days) contained 3,000 kcal metabolizable energy $/ \mathrm{kg}, 21.4 \%$ crude protein, $1.263 \%$ Lysine, $0.561 \%$ Methionine, $0.960 \%$ Calcium, and $0.450 \%$ available phosphorus. Other nutritional levels were as recommended by Rostagno et al. (2000).

\section{- Statistical Analysis}

Analysis of variance was performed using the software Estat 2.0 (1992) and the contrasts between treatment means were evaluated by the Tukey test at a significance level of $5 \%(p<0.05)$.

\section{- Evaluated parameters}

\section{- Intestinal mucosa histology (Light microscopy)}

Birds were slaughtered after a period of fasting (12 hours) and samples of duodenum, jejunum and ileum were fixed in Bouin solution for 48 hours. The tissue fragments were then dehydrated by immersion in a graded series of alcohols of increasing concentration (from $70 \%$ to absolute), infiltrated with xylene, and embedded in paraffin. A microtome was used to make $5-\mathrm{mm}$ cuts that were mounted in glass slides and stained with Masson's trichrome. Villus height and crypt depth $(\mu \mathrm{m})$ were determined using an image analyzer (Kontron Elektronik $\mathrm{GmbH}$ ) coupled to a binocular microscope (Carl Zeiss). Fifty readings of villus height and crypt depth were performed per treatment and per intestinal segment, with a total of 2,700 readings that were documented in a photomicroscope Axioskop (Zeiss). Villus height was measured from the apical to the basal region, which corresponded to the superior portion of the crypts. Crypts were measured
Intestinal Mucosa Development in Broiler Chickens Fed Natural Growth Promoters

from the basis until the region of transition between the crypt and the villus.

\section{- Ultra-Structure of the Intestinal Mucosa (Scanning Electron Microscopy)}

After a period of fasting (12 hours) intestinal samples of duodenum, jejunum and ileum were collected at slaughter to be analyzed by scanning electron microscopy. Samples were fixed in glutaraldehyde solution for 24 hours and washed with phosphate buffer $0.1 \mathrm{M}, \mathrm{pH}$ 7.4. They were fixed in $1 \%$ osmium tetroxide for $2 \mathrm{~h}$, washed again in phosphate buffer and dehydrated by transferring through a series of ethanol with increasing concentrations $(30 \%, 50 \%, 70 \%, 80 \%, 95 \%$ and $100 \%)$. Three washes were performed with $100 \%$ ethanol. The samples were submitted to drying with liquid $\mathrm{CO}_{2}$ in a Bal-Tec Critical Point Drying apparatus, mounted on copper grids, and sputter-coated with gold using a Denton Vacuum Desk II Coater. Samples were examined in a Jeol-Jsm 5410 scanning electron microscope. Electron micrographs were made at three different fields to determine the number of villus. The photo area was calculated based on the width and length of the observation field, considering the scale of each photo. The villi were counted in each field, with a total of 324 readings (36 birds / 3 intestinal segments / 3 fields), and expressed as the ratio villus number $/ \mathrm{mm}^{2}$.

\section{RESULTS AND DISCUSSION}

Villus height $(\mathrm{VH})$ in the different segments of the small intestine of broilers fed with probiotics and prebiotics is shown in Table 1. Villi were higher $(p<0.01)$ in the duodenum of birds fed without prebiotics compared to the birds fed prebiotics based in MOS and OA or MOS-based prebiotics. These results are different from results previously reported by Macari \& Maiorka (2000) and Loddi (2003), who described higher villi in the intestinal mucosa of birds fed diets with MOS at 7 and 21 days of age, respectively.

Higher villi in the jejunum $(p<0.01)$ were seen when Bacillus subtilis-based probiotics were used compared to diets without this additive (Figure 1). A previous study showed that $\mathrm{VH}$ at 42 days of age was numerically superior in the jejunum of birds fed probiotics based on Bacillus sp and Lactobacillus sp in the diet and water when compared to control birds (Pelicano et al., 2003).

Diets based on prebiotics with MOS + OA resulted in higher villi in the jejunum $(p<0.01)$, followed by the 
Pelicano ERL, Souza PA, Souza HBA, Figueiredo DF, Boiago MM, Carvalho SR, Bordon VF

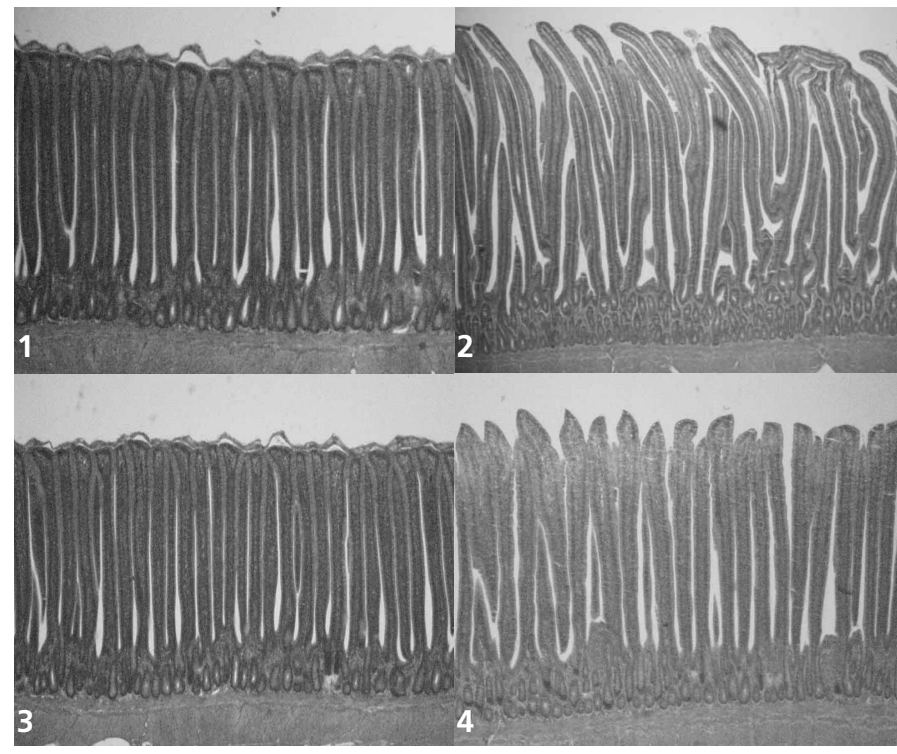

Figure 1 - Villus height in the jejunum and ileum of broilers fed diets containing or not probiotics at 21 days of age. 1 - Control/ Jejunum; 2 - Bacillus subtilis /Jejunum; 3 - Control/lileum; 4 Bacillus subtilis /ĺleum.

diets containing MOS-based prebiotics and finally the diets without prebiotics (Figure 2). According to lji \& Tivey (1998), some bacteria may recognize binding sites on the prebiotics as if they were from the intestinal mucosa, and the colonization of the intestine by
Intestinal Mucosa Development in Broiler Chickens Fed Natural Growth Promoters

pathogenic bacteria is thus reduced. Therefore, besides a lower infection incidence, there is an increase in the absorption of available nutrients, a mechanism that directly affects the recovery of the intestinal mucosa, increasing VH. Radecki \& Yokoyama (1991) stated that when prebiotics are added to the diet, they are fermented and the growth and stability of specific bacterial populations that produce organic acids are stimulated. Therefore, the lumen $\mathrm{pH}$ decreases and, together with other antibacterial substances and enzymes produced by the same microbiota, inhibits pathogenic microorganisms that are sensitive to acid $\mathrm{pH}$, such as Escherichia coli, Clostridium sp and Salmonella. Thus, the higher villi may have resulted from the action of organic acids (those added to the diet with the prebiotics in conjunction with the acids produced by the microbiota), which contributed to a more effective $\mathrm{pH}$ reduction in the intestine and, consequently, reduced colonization of the intestine by enteropatogenic microorganisms.

Higher villi $(p<0.01)$ were seen in the ileum when the Bacillus subtilis-based probiotics were added compared to the diets without this growth promoter. The same result was seen in the diets without prebiotics or with prebiotics based on MOS + OA when compared to the treatments fed MOS-based prebiotics (Figures 1 and 2). The findings disagree with results reported

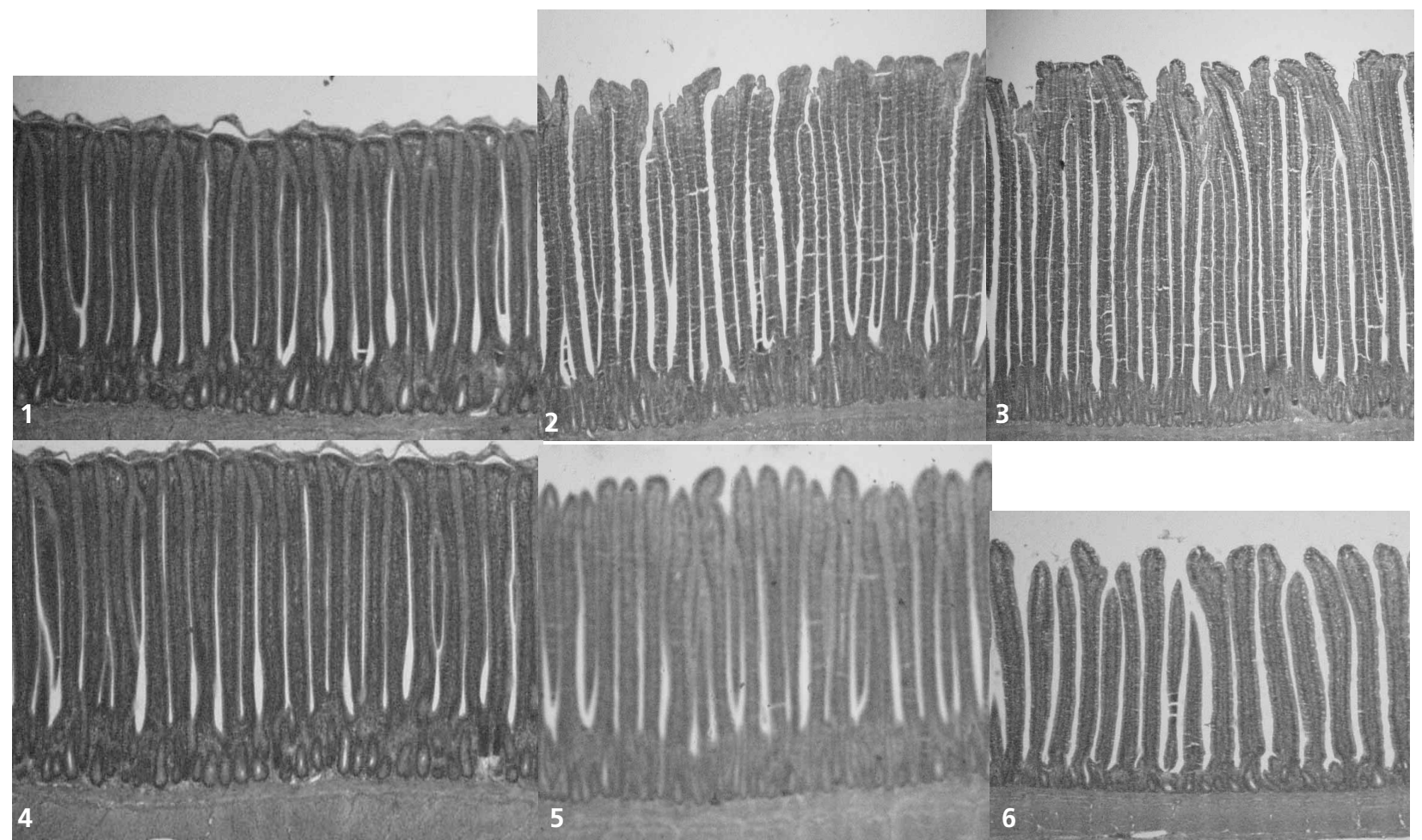

Figure 2 - Villus height in the jejunum and ileum of broilers fed diets containing or not prebiotics at 21 days of age. 1 - Control/ Jejunum; 2 - MOS + AO /Jejunum; 3 - MOS/Jejunum; 4 - Control/lleum; 5 - MOS + AO/Ileum; 6 - MOS /lleum. 
Pelicano ERL, Souza PA, Souza HBA, Figueiredo DF, Boiago MM, Carvalho SR, Bordon VF Natural Growth Promoters by Pelicano et al. (2003) and Loddi (2003), who reported no differences in $\mathrm{VH}$ in the ileum with the use of probiotics and prebiotics, respectively.

Table 1 also shows a significant interaction $(p<0.01)$ among the evaluated factors in all intestinal segments. The separate effects for the main factors are shown in Table 2.

\begin{tabular}{|c|c|c|c|}
\hline \multicolumn{4}{|c|}{$\begin{array}{l}\text { Table } 1 \text { - Villus height of broilers fed diets containing probiotics } \\
\text { and prebiotics at } 21 \text { days of age. }\end{array}$} \\
\hline \multirow{2}{*}{\multicolumn{2}{|c|}{$\begin{array}{ll}\text { Evaluated } & \text { V } \\
\text { Parameter } & \text { Duodenum } \\
\text { Probiotics in diet (PRO) }\end{array}$}} & \multicolumn{2}{|c|}{ Villus height $(\mu \mathrm{m})$} \\
\hline & & Jejunum & Ileum \\
\hline Control & 1441 & $1167^{b}$ & $898^{b}$ \\
\hline Pro $1^{(1)}$ & 1427 & $1243^{a}$ & $949^{a}$ \\
\hline Pro $2^{(2)}$ & 1438 & $1210 \mathrm{ab}$ & $933 a b$ \\
\hline F Test & 0.13 ns & $5.96 * *$ & $5.14 * *$ \\
\hline MSD (\%) & 66 & 52 & 38 \\
\hline \multicolumn{4}{|c|}{ Prebiotics in diet (PRE) } \\
\hline Control & $1539^{a}$ & $1131^{c}$ & $940^{a}$ \\
\hline Pre $1^{(3)}$ & $1401^{b}$ & $1271^{a}$ & $941^{a}$ \\
\hline Pre $2^{(4)}$ & $1366^{b}$ & $1218^{b}$ & $897^{b}$ \\
\hline F Test & $20.85 * *$ & $20.23 * *$ & $4.77 * *$ \\
\hline MSD (\%) & 66 & 52 & 38 \\
\hline PRO $\times$ PRE & $28.12 * *$ & $22.45 * *$ & $15.69 * *$ \\
\hline CV $(\%)$ & 17.05 & 15.87 & 15.22 \\
\hline
\end{tabular}

$a, b, c$ - Within the same factor, means followed by similar letters in the column are similar ( $p>0.05)$ by Tukey's Test. Test F: ns, nonsignificant; $* * p<0.01$. MSD - Minimal Significant Difference; CV Coefficient of Variation. (1)Probiotics based on Bacillus subtilis added to the diet throughout the experimental period, (2) Probiotics based on Lactobacillus acidophilus and casei, Streptococcus lactis and faecium, Bifidobacterium bifidum and Aspergillus oryzae added to the diet throughout the experimental period, (3)Prebiotics based on MOS and organic acidifier added to the diet throughout the experimental period, (4) Prebiotics based on MOS added to the diet throughout the experimental period.

Table 2 - Interaction effects (PRO $\times$ PRE) for villus height in the duodenum, jejunum and ileum of broilers fed diets containing probiotics and prebiotics at 21 days of age.

\begin{tabular}{lccc} 
Prebiotic in diet & \multicolumn{3}{c}{ Probiotic in diet } \\
\cline { 2 - 4 } $\begin{array}{l}\text { Duodenum } \\
\text { Control }\end{array}$ & Control & Pro 1(1) & Pro 2 ${ }^{(2)}$ \\
Pre 1(3) & & & \\
Pre 2 & $1328 \mathrm{Bb}^{(4)}$ & $1653 \mathrm{Aa}$ & $1634 \mathrm{Aa}$ \\
Jejunum & $1490 \mathrm{Aa}$ & $1426 \mathrm{Ab}$ & $1286 \mathrm{Bb}$ \\
Control & $1504 \mathrm{Aa}$ & $1202 \mathrm{Bc}$ & $1393 \mathrm{Ab}$ \\
Pre 1 & & & \\
Pre 2 & $976 \mathrm{Bc}$ & $1194 \mathrm{Ab}$ & $1224 \mathrm{Aa}$ \\
Ileum & $1214 \mathrm{Bb}$ & $1394 \mathrm{Aa}$ & $1204 \mathrm{Ba}$ \\
Control & $1312 \mathrm{Aa}$ & $1142 \mathrm{Bb}$ & $1201 \mathrm{Ba}$ \\
Pre 1 & & & \\
Pre 2 & $863 \mathrm{Cb}$ & $1020 \mathrm{Aa}$ & $938 \mathrm{Bb}$ \\
\hline
\end{tabular}

(*) Means followed by similar capital (small) letters within the rows (columns) are similar ( $p>0.05$ ) by Tukey's test. (1) Probiotics based on Bacillus subtilis added to the diet throughout the experimental period,(2)Probiotics based on Lactobacillus acidophilus and casei, Streptococcus lactis and faecium, Bifidobacterium bifidum and Aspergillus oryzae added to the diet throughout the experimental period, (3)Prebiotics based on MOS and organic acidifier added to the diet throughout the experimental period, (4)Prebiotics based on MOS added to the diet throughout the experimental period
In the duodenum, higher villi were seen when probiotics ( 1 and 2 ) and prebiotics (1 and 2) were used compared to the control group (no addition of natural growth promoters). These results were similar to findings reported by Pelicano et al. (2003) and Loddi et al. (2004) who found, respectively, lower VH in the duodenum of control birds compared with birds fed diets containing probiotics based on Bacillus subtilis, Bacillus licheniformis and Saccharomyces cerevisiae, and prebiotics based on MOS and organic acidifier (OA). However, the results are not in accordance with the findings obtained by Santos et al. (2004), who observed no differences in $\mathrm{VH}$ between the control group and birds receiving diets containing probiotics based on Lactobacillus acidophilus and casei, Streptococcus lactis and faecium, Bifidobacterium bifidum and Aspergillus oryzae or prebiotics based on MOS. Higher VH were obtained in the duodenum when Pro 1 and Pro 2 were used alone and when Pre 1 was used alone or in combination with Pro 1 and Pre 2 was used alone or in association with Pro 2.

Similarly, higher villi were observed in the jejunum when probiotics ( 1 and 2 ) and prebiotics ( 1 and 2 ) were used compared to the control group. According to Cera et al. (1988), maximum absorption and digestion capacity is given by a large luminal area with high villi and mature enterocytes, and is essential to animal development. Considering the association, higher $\mathrm{VH}$ were seen in the jejunum when Pro 1 was used in association with Pre 1, and vice-versa, and when Pre 2 was used alone.

In the ileum, higher villi were observed when probiotics (1 and 2) and prebiotics based on MOS were used, compared to the control group. These results disagree to those obtained by Pelicano et al. (2003) and Santin et al. (2001), respectively, who found no differences in ileum $\mathrm{VH}$ with the use of probiotics and prebiotics. Besides, higher VH were seen when Pro 1 or Pre 2 were used alone, and when Pro 2 was associated with Pre 1, and vice-versa.

Crypt depth (CD) in the different segments of the small intestine of broilers fed with probiotics and prebiotics is shown in Table 3.

All intestinal segments showed greater CD $(p<0.01)$ when probiotics based on Bacillus subtilis were added to the diet, and smaller in those diets without additives or with probiotics based in a bacterial pool. Similar results were reported by Pelicano et al. (2003), who also observed greater $C D$ in the intestinal mucosa of 42-day old broilers fed probiotics based on Bacillus sp. 
Pelicano ERL, Souza PA, Souza HBA, Figueiredo DF, Boiago MM, Carvalho SR, Bordon VF
Intestinal Mucosa Development in Broiler Chickens Fed Natural Growth Promoters
Greater $(p<0.01) C D$ in the duodenum and in the jejunum were seen when no prebiotics were used, compared to the groups fed such additives. These findings partially corroborate results described by Pluske et al. (1997), in which greater CD indicated high proliferative cellular activity, aiming to assure an adequate epithelium turnover rate, compensating for the losses in the $\mathrm{VH}$ as observed in the jejunum of the control group, but not in the duodenum.

Table 3 shows also a significant interaction $(p<0.01)$ between the studied factors in all intestinal segments. These findings corroborate partially results reported by Pelicano et al. (2003), in which a significant interaction $(p<0.01)$ between the studied factors in the duodenum, jejunum and ileum was observed with the use of probiotics.

\begin{tabular}{|c|c|c|c|}
\hline Evaluated & & Crypt dep & \\
\hline \multicolumn{3}{|c|}{ Probiotic in diet (PRO) } & Ileum \\
\hline Control & $247^{b}$ & $200^{b}$ & $203^{b}$ \\
\hline Pro $1^{(1)}$ & $264^{a}$ & $230^{a}$ & $223^{a}$ \\
\hline Pro $2^{(2)}$ & $237^{b}$ & $194^{b}$ & $192^{b}$ \\
\hline F Test & $7.92 * *$ & $35.57 * *$ & $12.21 * *$ \\
\hline MSD (\%) & 15 & 10 & 14 \\
\hline \multicolumn{4}{|c|}{ Prebiotic in diet (PRE) } \\
\hline Control & $273^{a}$ & $225^{a}$ & 210 \\
\hline Pre $1^{(3)}$ & $237^{b}$ & $201^{b}$ & 208 \\
\hline Pre $2^{(4)}$ & $237^{b}$ & $198^{b}$ & 200 \\
\hline F Test & $19.11 * *$ & $21.52 * *$ & $1.26 \mathrm{~ns}$ \\
\hline MSD (\%) & 15 & 10 & 14 \\
\hline PRO $\times$ PRE & $12.40 * *$ & $23.19 * *$ & 3.15 * \\
\hline CV (\%) & 23.47 & 18.80 & 26.60 \\
\hline
\end{tabular}

$a, b$ - Within the same factor, means followed by similar letters in the column are similar ( $p>0.05)$ by Tukey's Test. Test F: ns, non-significant; * $p<0.05 ; * * p<0.01$. MSD - Minimal Significant Difference; CV Coefficient of Variation. (1)Probiotics based on Bacillus subtilis added to the diet throughout the experimental period, (2) Probiotics based on Lactobacillus acidophilus and casei, Streptococcus lactis and faecium, Bifidobacterium bifidum and Aspergillus oryzae added to the diet throughout the experimental period, (3) Prebiotics based on MOS and organic acidifier added to the diet throughout the experimental period, (4) Prebiotics based on MOS added to the diet throughout the experimental period.

Greater CD in the duodenum were seen when probiotics (1 and 2) were used in relation to the control group (Table 4). These results corroborate reports from Santos et al. (2004) who found higher CD with the use of diets containing probiotics based on Lactobacillus acidophilus and casei, Streptococcus lactis and faecium, Bifidobacterium bifidum and Aspergillus oryzae, in relation to the control group. Greater CD was seen when Pro 1 and Pro 2 was used without prebiotics and when Pre 1 was used alone or associated to Pro 1 and Pre 2 was used alone.

\begin{tabular}{|c|c|c|c|}
\hline \multirow{2}{*}{ Prebiotic in diet } & \multicolumn{3}{|c|}{ Probiotic in diet } \\
\hline & Control & Pro $1^{(1)}$ & Pro $2^{(2)}$ \\
\hline \multicolumn{4}{|l|}{ Duodenum } \\
\hline Control & $234 \mathrm{Ca}$ & $308 \mathrm{Aa}$ & $278 \mathrm{Ba}$ \\
\hline Pre $1^{(3)}$ & $253 \mathrm{Aa}$ & $250 \mathrm{Ab}$ & $208 \mathrm{Bb}$ \\
\hline Pre $2^{(4)}$ & $254 \mathrm{Aa}$ & $233 \mathrm{ABb}$ & $225 \mathrm{Bb}$ \\
\hline \multicolumn{4}{|l|}{ Jejunum } \\
\hline Control & $186 \mathrm{Cb}$ & $276 \mathrm{Aa}$ & $213 \mathrm{Ba}$ \\
\hline Pre 1 & $213 \mathrm{Aa}$ & $208 \mathrm{Ab}$ & $182 \mathrm{Bb}$ \\
\hline Pre 2 & $201 \mathrm{Aab}$ & $205 \mathrm{Ab}$ & $187 \mathrm{Ab}$ \\
\hline \multicolumn{4}{|l|}{ Ileum } \\
\hline Control & $202 \mathrm{Ba}$ & $230 \mathrm{Aa}$ & $199 \mathrm{Ba}$ \\
\hline Pre 1 & $216 \mathrm{Aa}$ & $208 \mathrm{Aa}$ & $199 \mathrm{Aa}$ \\
\hline Pre 2 & $192 \mathrm{Ba}$ & $231 \mathrm{Aa}$ & $178 \mathrm{Ba}$ \\
\hline
\end{tabular}

(*) Means followed by similar capital (small) letters within the rows (columns) are similar ( $p>0.05$ ) by Tukey's test. (1) Probiotics based on Bacillus subtilis added to the diet throughout the experimental period, (2) Probiotics based on Lactobacillus acidophilus and casei, Streptococcus lactis and faecium, Bifidobacterium bifidum and Aspergillus oryzae added to the diet throughout the experimental period. (3) Prebiotics based on MOS and organic acidifier added to the diet throughout the experimental period. (4) Prebiotics based on MOS added to the diet throughout the experimental period

In the jejunum higher CD was obtained with the use of diets containing probiotics (1 and 2 ) and prebiotics based on MOS and OA, in relation to the control group. Schwarz et al. (2002) no observed differences in $C D$ of the jejunum between the control group and the birds receiving diets containing Bacillus subtilis, however, higher CD were seen when probiotics based on Lactobacillus fermentum was used. Santin et al. (2001) and Loddi et al. (2003), respectively, not observed differences in $C D$ of the jejunum with the use of diets containing prebiotics based on MOS and $O A$ at 21 days or with the use of diets containing Saccharomyces cerevisiae cell wall at 28 days of age, in relation to the control group. In the jejunum greater CD were obtained when Pro 1 and Pro 2 were used alone and when Pre 1 was used alone or associated with Pro 1

Higher CD in the ileum was obtained with the use of diets containing probiotics based on Bacillus subtilis, in relation to the control birds or the groups receiving diets containing a bacterial pool. These results are not in accordance with the findings obtained by Pelicano et al. (2003) who not observed difference in CD of the ileum between the control groups and the groups receiving diets containing probiotics. Besides, greater $C D$ in the ileum were obtained when Pre 2 was used together with Pro 1.

Data of villus density (VD) per segment of the small intestine are shown in Table 5. Density decreased in the following order: ileum, jejunum and duodenum. 
Pelicano ERL, Souza PA, Souza HBA, Figueiredo DF, Boiago MM, Carvalho SR, Bordon VF
These results corroborate reports from Yamauchi \& Ishiki (1991).

\begin{tabular}{|c|c|c|c|}
\hline \multirow{2}{*}{$\begin{array}{l}\text { Evaluated } \\
\text { Parameter }\end{array}$} & \multicolumn{3}{|c|}{ Villus density } \\
\hline & Duodenum & Jejunum & Tleum \\
\hline \multicolumn{4}{|c|}{ Probiotic in diet (PRO) } \\
\hline Control & 41 & 47 & 56 \\
\hline Pro $1{ }^{(1)}$ & 37 & 51 & 66 \\
\hline Pro $2^{(2)}$ & 43 & 48 & 67 \\
\hline F Test & $1.87 \mathrm{~ns}$ & $0.46 \mathrm{~ns}$ & $3.04 \mathrm{~ns}$ \\
\hline MSD (\%) & 8.62 & 10.69 & 12.28 \\
\hline \multicolumn{4}{|c|}{ Prebiotic in diet (PRE) } \\
\hline Control & 39 & 51 & 64 \\
\hline Pre $1^{(3)}$ & 40 & 43 & 63 \\
\hline Pre $2^{(4)}$ & 42 & 52 & 64 \\
\hline F Test & $0.52 \mathrm{~ns}$ & $2.78 \mathrm{~ns}$ & $0.05 \mathrm{~ns}$ \\
\hline MSD (\%) & 8.62 & 10.69 & 12.28 \\
\hline PRO $\times$ PRE & 2.94 * & $1.78 \mathrm{~ns}$ & $0.31 \mathrm{~ns}$ \\
\hline CV $(\%)$ & 21.18 & 21.85 & 19.14 \\
\hline
\end{tabular}

Within the same factor, means followed by similar letters in the column are similar ( $p>0.05$ ) by Tukey's Test. Test F: ns, non-significant; * $p<0.05$. MSD - Minimal Significant Difference; CV - Coefficient of Variation. (1)Probiotics based on Bacillus subtilis added to the diet throughout the experimental period, (2)Probiotics based on Lactobacillus acidophilus and casei, Streptococcus lactis and faecium Bifidobacterium bifidum and Aspergillus oryzae added to the diet throughout the experimental period, (3)Prebiotics based on MOS and organic acidifier added to the diet throughout the experimental period, (4)Prebiotics based on MOS added to the diet throughout the experimental period.

There were no differences in the density of villi between the groups receiving probiotics and prebiotics and the groups without addition of the respective additives, in all evaluated intestinal segments. These findings corroborate partially results reported by Loddi (2003), in which no difference in VD in the duodenum and jejunum was seen with the use of probiotics and prebiotics, although higher densities were seen in the ileum at 21 days of age with the use of prebiotics containing MOS + lactose, when compared to the control group and the groups fed probiotics and symbiotics.
Independent of the use of growth promoters, the morphology of the villus in the present study was similar to the morphology reported in the literature. Villus in the duodenum were more scattered, in lower number and were leaf-shaped, similar to the descriptions reported by Yamauchi \& Ishiki (1991) and Sato (2001). In the jejunum, the villus were arranged as in zig-zag, resembling a wave, results similar to those reported by Pelicano et al. (2003). According to Yamauchi \& Ishiki (1991), nutrient absorption is more efficient when villi are organized like this than if they are in parallel or randomly positioned. This would occur because the passage of food through the alimentary canal would take longer in the zigzag flux than in the straight flux, and the contact between the nutrients and the absorption surface of the intestinal epithelium would be better. The villi in the ileum were tongue-shaped and density was very high in all treatments, making it difficult to individualize them.

There was a significant interaction $(p<0.05)$ between factors for VD in the duodenum. The separate effects of the factors are shown in Table 6 and Figure 3.

\begin{tabular}{|c|c|c|c|}
\hline \multirow[t]{2}{*}{ Prebiotic in diet } & \multicolumn{3}{|c|}{$\begin{array}{c}\text { Probiotic in diet } \\
\end{array}$} \\
\hline & Control & Pro $1^{(1)}$ & Pro $2^{(2)}$ \\
\hline Control & $39 \mathrm{ABa}$ * & $27 \mathrm{Bb}$ & $51 \mathrm{Aa}$ \\
\hline Pre $1^{(3)}$ & $40 \mathrm{Aa}$ & $40 \mathrm{Aab}$ & $38 \mathrm{Aa}$ \\
\hline Pre $2^{(4)}$ & $43 \mathrm{Aa}$ & $43 \mathrm{Aa}$ & $41 \mathrm{Aa}$ \\
\hline
\end{tabular}

(*) Means followed by similar capital (small) letters within the rows (columns) are similar ( $p>0.05$ ) by Tukey's test. (1) Probiotics based on Bacillus subtilis added to the diet throughout the experimental period, (2) Probiotics based on Lactobacillus acidophilus and casei, Streptococcus lactis and faecium, Bifidobacterium bifidum and Aspergillus oryzae added to the diet throughout the experimental period, (3)Prebiotics based on MOS and organic acidifier added to the diet throughout the experimental period, (4) Prebiotics based on MOS added to the diet throughout the experimental period.
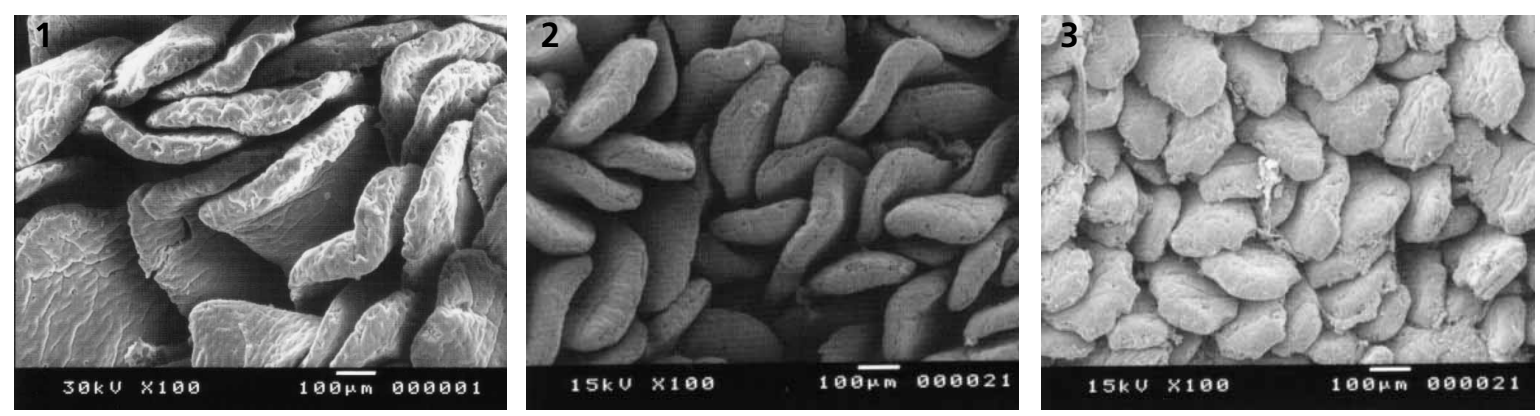

Figure 3 - Villus density (villus number / $1.145 .306 \mu \mathrm{m}^{2}$ ) in the duodenum of broilers fed diets containing probiotics and prebiotics at 21 days of age. 1 - Bacillus subtilis, 2 - Bacillus subtilis + MOS; 3 - Lactobacillus acidophilus and casei, Streptococcus lactis and faecium, Bifidobacterium bifidum and Aspergillus oryzae. 
Pelicano ERL, Souza PA, Souza HBA, Figueiredo DF, Boiago MM, Carvalho SR, Bordon VF

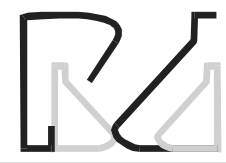

VD was higher when probiotics based on Bacillus subtilis were used together with prebiotics based on MOS, compared to the use of probiotics based on Bacillus sp alone. It was also higher in the birds fed the probiotics containing a bacterial poo/compared to those containing only one culture (probiotic 1). The results suggest that, in order to obtain higher VD (consequently higher nutrient absorption area), it is necessary to use MOS-based saccharides when probiotics based in only one bacterial culture are used. On the other hand, they would be not necessary if the probiotics has many bacterial cultures, as observed for probiotic 2 .

\section{CONCLUSION}

Beneficial effects were seen in histological indexes of the intestinal mucosa with the use of probiotics and prebiotics at 21 days of age.

\section{REFERENCES}

Bradley GL, Savage TF, Timm KI. The effects of supplementing diets with Saccharomyces cerevisiaevar. boulardii on male poultry performance and ileal morphology. Poultry Science 1994; 73:1766-1770.

Cera, KR, Mahan DC, Cross RF, Reinhart GA, Whitmoyer RE. Effect of age, weaning and posweaning diet on small intestinal growth and jejunal morphology in young swine. Journal of Animal Science 1988; 66:574-584.

Choi KH, Namkung $H$, Paik IK. Effects of dietary fructooligosaccharides on suppression of intestinal colonization of Salmonella typhimurium in broiler chickens. Korean Journal of Animal Science 1994; 36:71-284.

Dionizio MA. Prebióticos como promotores de crescimento para frangos de corte [dissertação]. Lavras: Universidade Federal de Lavras; 2001.

Dobrogsz WJ, Black BL, Casas IA. Delivery of viable Lactobacillus reuterito the gastrointestinal tract of poultry. Poultry Science 1991; 70:158.

Estat 2.0 Sistema de Análise Estatística. Jaboticabal: Polo Computacional, Departamento de Ciências Exatas, FCAV, UNESP; 1992.

Ewing WN, Cole DJA. The living gut: na introduction to microorganisms in nutrition. Dungannon, UK: Context Publication; 1994. 220 p.

Hofacre CL, Beacorn T, Collett S, Mathis G. Using competitive exclusion, mannan-oligosaccharide and other intestinal products to control necrotic enteritis. Journal Applied Poultry Research 2003; 12:60-64.
Intestinal Mucosa Development in Broiler Chickens Fed Natural Growth Promoters

Hofstad MS, editor. Diseases of poultry. $6^{\text {th }}$ ed. Ames: The lowa State University Press; 1972. 1176p.

Iji PA, Tivey DR. Natural and synthetic oligosaccarides in broiler chicken diets. Word's Poultry Science Journal 1998; 54:129-143.

Loddi MM. Probióticos, prebióticos e acidificante orgânico em dietas para frangos de corte [tese]. Jaboticabal: FCAV, UNESP; 2003.

Loddi MM, Moraes VMB, Nakaghi LSO, Tucci FM, Hannas MI, Ariki JÁ. Mannan oligosaccharide and organic acids on performance and intestinal morphometric characteristics of brolier chickens. In: Proceedings of the 20 th Annual Symposium; 2004; Suppl. 1, p.45.

Macari M, Maiorka A. Função gastrintestinal e seu impacto no rendimento avícola. In: Anais da Conferência Apinco de Ciência e Tecnologia Avícolas; 2000; Campinas: FACTA, 2000. v.2. p.161174

Oliveira PB. Influência de fatores antinutricionais de alguns alimentos sobre o epitélio intestinal e o desempenho de frangos de corte [Dissertação]. Maringá: Universidade Estadual de Maringá; 1998.

Pelicano ERL, Souza PA, Souza HBA. Prebióticos e Probióticos na nutrição de aves. Ciências Agrárias e da Saúde 2002; 2(1):59-64.

Pelicano ERL, Souza PA, Souza HBA, Oba A, Norkus EA, Kodawara LM, Lima TMA. Morfometria e ultra-estrutura da mucosa intestinal de frangos de corte alimentados com dietas contendo diferentes probióticos. Revista Portuguesa de Ciências Veterinárias 2003; 98 (547):124-134.

Pelicano ERL, Souza PA, Souza HBA, Oba A, Leonel FR, Zeola NMBL, Boiago M.M. Utilização de probióticos e/ou prebióticos como promotores de crescimento em rações iniciais de frangos de corte. Revista Brasileira de Ciência Avícola 2004; (supl. 6):17.

Pluske JR, Hampson DJ, Williams IH. Factors influencing the stricture and function of the small intestine en the weaned pig: a review. Livestock Production Science 1997; 51:215-236.

Podolsky DK. Regulation of intestinal epithelial proliferation: a few answers, many questions. Animal Journal Physiologic 1993; 264, p:G179-G186.

Radecki SY, Yokoyama MT. Intestinal Bacteria And Their Influence On Swine Nutrition. In: Miller, E.R., Duane, E.U., Lewis, A.J. Swine nutrition. Boston: Butterworth-Heinemann; 1991. p.439-447.

Rostagno HS, Albino LFT, Donzele JL, Gomes PC, Ferreira AS, Oliveira RF, Lopes DC. Tabelas brasileiras para aves e suínos: composição de alimentos e exigências nutricionais. Viçosa: Horacio Rostagno; 2000. $141 p$

Santin E, Maiorka A, Macari M, Grecco M, Sanchez JC, Okada TM, Myasaka AM. Performance and intestinal mucosa development of broiler chickens fed diets containing Saccharomyces cerevisiae cell wall. Journal Applied Poultry Research 2001; 10:236-244.

Santos EC, Teixeira AS, Freitas RTF, Dias ES, Rodrigues PB, Murgas LDS, Oliveira RFM, Santos EC, Gachett NAB. Uso de promotores de 
Pelicano ERL, Souza PA, Souza HBA,

Figueiredo DF, Boiago MM,

Carvalho SR, Bordon VF

crescimento sobre o desempenho e morfometria intestinal de frangos de corte na fase inicial. In: Anais da 41 a Reunião Anual da Sociedade Brasileira de Zootecnia; 2004; Campo Grande. CD ROM.

Sato RN. Ação isolada e combinada de probiótico e antibiótico como promotores de crescimento em rações iniciais de frangos de corte [Trabalho de Graduação]. Jaboticabal: FCAV, UNESP; 2001.

Savage TF, Cotter PF, Zakrewska El. Effect of feeding a mannanoligosaccharide on immunoglobulin, plasma IgG and bile IgA of Wrolstad MW male turkey. Poultry Science 1996; 75 (suppl. 1):143.

Schwarz KK, Franco SG, Fedalto LM, Borges SA, Fisher da Silva AV, Pedroso AC. Efeitos de antimicrobianos, probióticos, prebióticos e simbióticos sobre o desempenho e morfologia do jejuno de frangos. Brazilian Journal of Poultry Science 2002; (supl. 4):75.

Spring P. Effects of mannanoligosaccharide on different cecal parameters and on cecal concentrations of enteric pathogens in poultry. Dissertation (ETH no. 11897). ETH Zurich, Switzerland. 1996. Vicent JG. Antibacterial activity associated with Lactobacillus acidophilus. Journal of Bacteriology 1959; 78:477-484.

Visek WJ. The mode of Growth Promotion by Antibiotics. Journal of Animal Science 1978; 46:1447-1469.

Walker WA, Duff LC. Diet and bacterial colonization: Role of probiotics and prebiotics. Journal Nutrition Biochemical 1998; 9:668-675.

Yamauchi KE, Ishiki Y. Scanning electron microscopic observations on the intestinal villi in growing White Leghorn and broiler chickens from 1 to 30 days of age. British Poultry Science 1991; 32: 67-78. 


\section{FACTA}

\section{PUBLICAÇÕES FACTA}

Anais da Conferência APINCO'94

Anais da Conferência APINCO'95

Anais da Conferência APINCO'97

Anais da Conferência APINCO'98

Anais da Conferência APINCO'99 (2 vol)

Anais da Conferência APINCO’00 (2 vol)

Anais da Conferência APINCO'02 (1 vol)

Anais da Conferência APINCO'03 (1 vol)

Anais da Conferência APINCO'05 (2 vol)

II Simpósio Internacional de Coccidiose Aviária

Col. FACTA - Manejo de Frangos

Il Simpósio da Doença de Gumboro

Simpósio FACTA de Postura Comercial

Doença das Aves

Fisiologia Aviária

Manejo da Incubação

Produção de Frangos de Corte

Manejo de Matrizes de Corte

Para maiores informações:

facta@facta.org.br ou Fone: (19) 3243-6555 